\title{
The Right to Education in the Era of the ASEAN Community
}

\author{
A Hope for the Regional Human Rights System
}

\author{
Ratna Juwita \\ PhD Candidate, Department of Transboundary Legal Studies, \\ Faculty of Law, University of Groningen, Groningen, the Netherlands; \\ Assistant Professor, Department of International Law, Faculty of Law, \\ Universitas Atma Jaya Yogyakarta, Yogyakarta, Indonesia \\ r.juwita@rug.nl; ratna.juwita@uajy.ac.id
}

\begin{abstract}
The establishment of the Association of Southeast Asian Nations (ASEAN) Community in 2015, marked a milestone of progressive regionalisation in the Southeast Asia region. The ASEAN Intergovernmental Commission on Human Rights (AICHR) and ASEAN Commission on the Promotion and Protection of the Rights of Women and Children (ACWC) were designated as pivotal organs to strengthen the realisation of the right to education as part of the rights guaranteed in the ASEAN Declaration of Human Rights. The ASEAn Political-Security and Socio-Cultural communities recognise the importance of human rights. This research analyses the realisation of the right to education by the ASEAN member states. The Concluding Observations from international human rights monitoring organs are explored to describe the empirical situation of each member state. Subsequently, this article scrutinises the AICHR and ACWC within the framework of the ASEAN community and critically assesses the realisation of the right to education under the works of the AICHR and ACWC. This article concludes the realisation of the right to education in ASEAN is still challenging due to the problems of, inter alia, low allocation of resources in the education sector, high illiteracy and drop-out rates, gender discrimination in the non-traditional study program and access to quality education, especially for vulnerable groups. The AICHR and ACWC have not yet formulated specific formal instruments to address these situations. Since their respective establishment only a minor contribution has been made to advance the realisation of the right to education in the ASEAN community. In order to protect the right to education, the AIC H R and ACWC have to be strengthened institutionally and financially. It is also necessary to empower the
\end{abstract}


AICHR and ACWC by a quasi-legal authority to assess and inquire the ASEAN member states' human rights' performance. This step is a necessary for the AICHR and ACWC to make a tangible contribution to the realisation of the right to education in ASEAN.

\section{Keywords}

ASEAN Community - AICHR - ACWC - the right to education - human rights

Being seen by the international community as the regional organisation with the least developed regional human rights system since its establishment in 1967 , ASEAN took a further step of regionalisation in 2015 by inaugurating the ASEAN Community. ${ }^{1}$ The blueprint of ASEAN Community offers a stronger designated regional organisation with aims to unify the three pillars (the political-security community, economy community and socio-cultural community) of ASEAN society. ${ }^{2}$ This article is divided into three parts. The first explains the right to education in ASEAN. Thorough research was conducted to analyse the Concluding Observations from the international human rights monitoring organs which have been ratified by the ASEAN member states. The second explains the legal mandates of the AICHR and ACWC and the work that has been done in the education sector. The third analyses das sein and das sollen concerning the compatibility of the current AICHR and ACWC legal mandates with the empirical situation of the realisation of the right to education in ASEAN member states. The purpose of this article is to contribute to strengthening the human rights protection in ASEAN member states through

* The author is deeply grateful to Universitas Atma Jaya Yogyakarta (Internal Research Grant 2018) and Indonesia Endowment Fund for Education (LPDP) for providing full support for this study.

1 Cornelia Bayer, Counterterrorism and International Power Relations: The EU, ASEAN and Hegemonic Global Governance (Tauris Academic Studies 2010) 102; Opinion Asia, 'ASEAN's Toothless Council', Wall Street Journal (22 July 2009) <www.wsj.com/articles/ SB10oo14240529702O3517304574303592053848748> accessed 3 October 2O2O; ASEAN Trade Union Council, 'ASEAn Human Rights Commission Toothless: ngos', AsEAN Trade Union Council (8 May 2012) <aseantuc.org/2012/o5/asean-human-rights-commission\%E2\%8०\%98toothless\%E2\%8०\%99-ngos/> accessed 3 October 2020; Connie Levett, 'Toothless Tiger ASEAN Hopes to Replace Polite Silence with A Roar' the Sydney Morning Herald (13 January 2007) <www.smh.com.au/world/toothless-tiger-asean-hopes-to-replacepolite-silence-with-a-roar-20070113-gdp8g2.html > accessed 3 October 2020.

2 ibid. 
the utilisation of the AICHR as the main human rights regional body and the ACWC as the supplementary regional human rights body. The ASEAN community blueprint offers the world the hope of a prosperous ASEAN community; the protection of human rights is the key to reaching that ideal. ${ }^{3}$ This article emphasises that the AICHR and ACWC are the tools to assist in the actual fulfillment of the promises of human rights protection.

\section{The Right to Education in ASEAN: Assessment from the International Human Rights Monitoring Bodies}

The right to education is one of the rights guaranteed by international human rights law. International legal sources for the right to education include the Universal Declaration of Human Rights ${ }^{4}$ (Article 26), ${ }^{5}$ the International Covenant on Economic, Social and Cultural Rights (Article 13 and 14 ), ${ }^{6}$ and the

3 Ooi Ke Beng, 'Southeast Asia: No Longer Peripheral to Global Events' in Alan Chong (ed), International Security in the Asia-Pacific, Transcending ASEAN Towards Transnational Polycentrism (Palgrave Macmillan 2018) 43-6o.

4 Universal Declaration of Human Rights, UN GA Res 217 (III), 3rd Session, Supp. No. 13, UN Doc A/810 (1948) 71 (UDHR). Although the UDHR is not a legally binding international instrument, it is considered legitimate by the international community due to its wide acceptance in international relations. The UN General Assembly cited the UDHR in its resolutions several times signifying its importance. Statute of the International Court of Justice, 26 June 1945, 33 UnTs 993, art. 38; Jack Donnelly, Universal Human Rights in Theory and Practice (3rd edn, Cornell University Press 2013) 24-27; Philip Alston and Ryan Goodman, International Human Rights, the Successor to International Human Rights Context (OUP 2013) 144; Rhona KM Smith, Textbook on International Human Rights (4th edn, OUP 2010) 37; Javaid Rehman, International Human Rights Law, Second Edition (Pearson Education Limited 2010) 80-82; 'About the Universal Declaration of Human Rights Translation Project' (Office of the High Commisioner for Human Rights) <www.ohchr.org/en/udhr/pages/introduction.aspx > accessed 3 October 2020; 'Universal Declaration of Human Rights' (United Nations) <http://legal.un.org/avl/ha/ udhr/udhr.html > accessed 3 October 2020 .

5 Article 26 of the UDHR states:I. Everyone has the right to education. Education shall be free, at least in elementary and fundamental stages. Elementary education shall be compulsory. Technical and professional education shall be made generally available and higher education shall be equally accessible to all on the basis of merit.II. Education shall be directed to the full development of the human personality and the strengthening of respect forhuman rights and fundamental freedoms. It shall promote understanding, tolerance and friendship among all nations, racial, religious groups, and shall further the activities of the United Nations for the maintenance of peace.III. Parents have a prior right to choose the kind of education that shall be given to their children.

6 International Covenant on Economic, Social and Cultural Rights (entered into force 3 January 1976 ) G. A. res. 2200A (xxI), 21 U. N. GAOR Supp. (No. 16) at 49, U. N. Doc. A/6316 (1966), 993 UNTS 3 . 
Convention on the Rights of the Child (CRC) (Article 28 and 29). ${ }^{7}$ Progressively, the international human rights instruments are supported by regional human rights instruments. Concerning the right to education in Europe, the Revised European Social Charter, the Council of Europe Framework Convention for the Protection of the National Minorities and the European Union Charter of Fundamental Rights are the relevant regional human rights instruments. ${ }^{8}$ The Organization of American States (OAS) successfully negotiated several regional human rights instruments concerning the right to education in the Charter of the OAs, the American Declaration of the Rights and Duties of Man and the Additional Protocol to the American Convention on Human Rights in the Area of Economic, Social and Cultural Rights. ${ }^{9}$

Article $3^{1}$ of the ASEAN Human Rights Declaration affirms the right to education:

1. Every person has the right to education.

2. Primary education shall be compulsory and made available free to all. Secondary education in its different forms shall be available and accessible to all through every appropriate means. Technical and vocational education shall be made generally available. Higher education shall be equally accessible to all on the basis of merit.

3. Education shall be directed to the full development of the human personality and the sense of his or her dignity. Education shall strengthen the respect for human rightsand fundamental freedoms in ASEAN Member States. Furthermore, education shall enable all persons to participate effectively in their respective societies, promote understanding, tolerance and friendship among all nations, racial and religious groups, and enhance the activities of ASEAN for the maintenance of peace. ${ }^{10}$

The ASEAN Human Rights Declaration is the promise and hope for further human rights protection and fulfillment in the region. ${ }^{11}$ The Declaration

$7 \quad$ Convention on the Rights of the Child (November 1989) 1577 UNTS 3.

8 Revised European Social Charter (1 July 1999), CETS Number 163, art 17; Council of Europe Framework Convention for the Protection of the National Minorities (1 February 1998) CETS Number 156, art 12, 14; European Charter of Fundamental Rights (3 September 1953) 213 UNTS 222, art 14.

$9 \quad$ Charter of OAS (30 April 1948) 1609 UnTS 119, art 49; American Declaration of the Rights and Duties of Man (1992) OEA/Ser.L.V/11.82.Doc.6.rev, art XII; and Additional Protocol to the American Convention on Human Rights in the Area of Economic, Social and Cultural Rights (16 November 1999) OAs Treaty Series 69, art 13. ASEAN Human Rights Declaration, 2012, <www.asean.org/storage/images/ASEAN RTK_2014/6_AHRD_Booklet.pdf> accessed 3 October 2020 .

11 Gerard Clarke, 'The Evolving ASEAN Human Rights System: The ASEAN Human Rights Declaration of 2012' (2012) 11 Northwestern J Int'l Hum Rts 1, 1-27. 
strongly acknowledges the importance of human rights but does not specify the obligations of the member states.

The ratification of international human rights instruments plays a pivotal role in the legal certainty of State parties' human rights obligations concerning the right to education in ASEAN. As seen in Appendix 1, the Philippines, Cambodia and Indonesia have ratified most international human rights instruments. The right to education is specifically regulated in the ICESCR (Articles 13 and 14) and $\mathrm{CRC}^{12}$ (Article 28), though Brunei Darussalam and Singapore have yet to ratify the ICESCR. All ASEAN Member States have ratified the CRC, and thus State party human rights obligations concerning the right to education can be derived from the CRC. With regard to the freedom of people, Clarke elaborates on the Freedom House finding that Indonesia is the only country in ASEAN that can be labeled as 'free..$^{13}$ Freedom House categorised Malaysia, the Philippines, Singapore and Thailand as partly free and the other ASEAN member states, namely, Brunei, Cambodia, Laos, Myanmar and Vietnam are not free. ${ }^{14}$

The realisation of the right to education is being assessed through the reports from the international human rights monitoring organs namely the Committee on Economic, Social and Cultural Rights (Comm ESCR), the Committee on the Rights of the Child (Comm RC), the Committee on the Elimination of All Forms of Discrimination Against Women (Comm EDAW), the Committee on the Elimination of Racial Discrimination (Comm ERD) and the Committee on the Rights of Persons with Disabilities (Comm RPD). The Concluding Observations concerning the right to education of all ASEAN Member States were carefully selected and assessed based on their ratifications respectively. This step aims to provide an empirical description of the current realisations of the right to education in ASEAN.

First, Indonesia has been praised as an example where Islam, democracy, human rights and tolerance co-exist. ${ }^{15}$ After the reformation in 1998, Indonesia transitioned from an authoritarian government to a newly democratic government. ${ }^{16}$ The changes in national law are various, from amendments to the Constitution limiting the presidential terms and adding human rights provisions. ${ }^{17}$

\footnotetext{
12 Convention on the Rights of the Child ( $\left.n_{7}\right)$.

13 Clarke (n 11).

14 ibid.

15 Amitav Acharya, Indonesia Matters: Asia's Emerging Democratic Power (World Scientific Publishing Co 2014) 20.

16 ibid.

17 Amitav Archarya, Constructing a Security Community in Southeast Asia: ASEAN and the Problem of Regional Order (Routledge 2001) 21.
} 
However, though praised as having succeded in changing the authoritarian government institution, Vermonte concludes that Indonesia's democratic culture remains weak. ${ }^{18}$ Vermonte explains that "procedural democracy" and "substantive democracy" are two different issues and in Indonesia, the latter is weaker than the former. ${ }^{19}$ With regard to the right to education, the Comm ESCR expressed concerns with the lack of education services, or their poor quality, in some areas, contributing to a high number of illiterate persons in Indonesia. ${ }^{20}$ The Comm ESCR urged Indonesia to ensure quality and culturally adequate education, with the focus on people in rural areas. ${ }^{21}$

Primary education in Indonesia is not yet free of charge and the drop-out rate is high amongst girls. ${ }^{22}$ With regard to higher education, the Comm ESCR recommended the process of privatisation of higher education in Indonesia be accompanied by measures ensuring it remains equally accessible to all. ${ }^{23}$ The Comm RC focused on the matter of resource allocation. ${ }^{24}$ It regretted that the education budget in Indonesia was insufficient to ensure education for all children in the State party. ${ }^{25}$ Due to that situation, it recommended that Indonesia establish mechanisms to monitor and evaluate the adequacy, efficacy and equitability of the distribution of resources allocated to the implementation of the CRC. ${ }^{26}$

Singapore is an anomaly if one assumes human rights will only flourish in a liberal democratic country. Despite being labeled by many as a semi-authoritarian country that represses civil and political rights, Singapore successfully provides for the welfare of its people. ${ }^{27}$ The Comm RC recognised the high level of academic excellence delivered by the school system in Singapore. However, it also recommended that Singapore ensure all children have access to free primary school and support for minority students be provided. ${ }^{28}$ Particularly,

\footnotetext{
18 ibid $25^{-26 .}$

19 ibid.

20 'Concluding Observations on Indonesia' (Comm ESCR E/C.12/IDN/CO/1 2014) 12-13 [36].

21 ibid.

22 ibid.

23 ibid.

24 'Concluding Observations on Indonesia' (Comm RC CRC/C/IDN/CO/3-4 2014) 4 [15].

25 ibid.

26 ibid.

27 Simon SC Tay, 'Human Rights, Culture and the Singapore Example' (1996) 41 McGill LJ 743-780; Mark Beeson, Institutions of the Asia Pacific: ASEAN, APEC and Beyond (Routledge 2009) 14-15.

28 'Concluding Observations on Singapore' (Comm RC CRC/SGP/CO/2-3 2011) 12 [59]. The recommendations with regard to human rights education are reiterated in the subsequent 'Concluding Observations on Singapore' (Comm RC CRC/C/OPAC/SGP/CO/1 2014) 3 [13-14]; 'Concluding Observations on Singapore' (Comm EDAW CEDAW/C/SGP/CO/Rev. 1 2012) $[20]$.
} 
the Comm RC recommended Singapore to undertake all necessary measures to ensure all children have access to free primary education, strengthen and accelerate efforts to support minority students and include human rights education in the official school curricula. ${ }^{29}$ The Comm EDAW focused its concern on the definition of equality and discrimination in the national law of Singapore and urged Singapore to define discrimination in compliance with the Convention on the Elimination of All Forms of Discrimination Against Women (CEDAW) and also prohibit all forms of discrimination against women on all grounds. ${ }^{30}$

Concerning Malaysia, the Comm RC regretted the high number of children not enrolled in primary school. ${ }^{31}$ It was also concerned about the regional disparities in the dropout rates. ${ }^{32}$ The Comm RC recommended that Malaysia ensure access to quality education by all children, take measures to prevent children from dropping out of primary and secondary education, strengthen protection for indigenous groups with regard to education, provide vocational education for children who do not attend or complete regular school education and lastly, include human rights education in the school curricula. ${ }^{33}$ The Comm EDAw highlighted the issue of gender domination concerning the right to education for women and girls in Malaysia; it noted women still remain underrepresented in traditionally male-dominated fields of study at tertiary level, inter alia, engineering, mathematics and physics. ${ }^{34}$ The Comm EDAW recommended that Malaysia take measures to encourage girls to choose non-traditional fields of study and careers such as engineering, mathematics and physics and also eliminate traditional stereotypes and structural barriers to help young women enroll in such fields. ${ }^{35}$

The Comm EDAw praised Brunei Darussalam for its legislative reforms in the education sector: the promulgation of the Compulsory Education Act which provides nine years of compulsory education for all girls and boys. ${ }^{36}$ Brunei Darussalam has a high literacy rate and a high level of enrolment of females in tertiary education. ${ }^{37}$ However, the Comm EDAW recommended

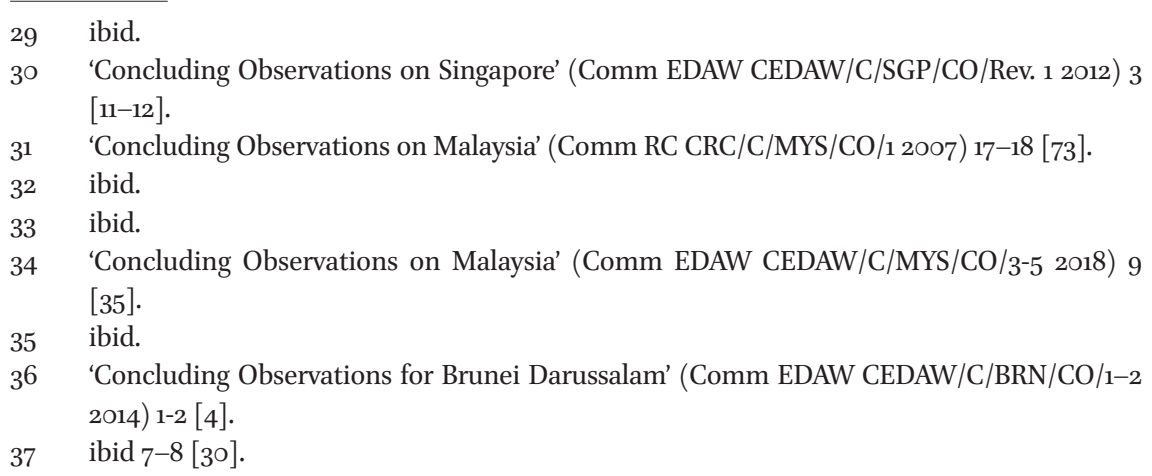


that Brunei Darussalam prioritise the elimination of negative stereotypes and structural barriers to the enrolment of girls in non-traditional fields of education at the secondary and tertiary levels and provide career counseling for girls on non-traditional career paths to ensure a corresponding transition into the labour market. ${ }^{38}$ The Comm RC also praised the Brunei Government for its legislative reforms concerning compulsory education. ${ }^{39}$

The Comm RC highlighted that Lao had to increase its budget allocation in education because the resources allocated fell short of the objective of a minimum 17 per cent. ${ }^{40}$ It also recommended the Lao Government take all the necessary measures to improve the accessibility and quality of education. ${ }^{41}$ The Comm ERD noted some ethnic groups in Lao did not have equal access to public services, including education. ${ }^{42}$ It noted the situations of high illiteracy and drop out rates amongst females. The Comm EDAW recommended that Lao ensure access to education for females (especially those in rural areas), eliminate discriminatory stereotypes, encourage school enrollment for females, and intensify efforts to provide non-formal education and adult literacy programmes. ${ }^{43}$

In respect of the Philippines, the Comm EDAW noted with concern the lower number of girls enrolled in pre-primary and primary education compared with boys. ${ }^{44}$ It also noted gender segregation in higher education in the case of low enrollment rates for females in non-traditional fields of study, inter alia, science, technology, engineering, mathematics and agriculture. ${ }^{45}$ The Comm EDAW recommended that the Philippines promote female enrolment in pre-primary and primary education, analyse the problem of drop-out and low enrollment rates of girls in education and overcome gender segregation to increase women's enrolment in non-traditional field of studies. ${ }^{46}$ Similar to the problem of resource allocation in Indonesia and Lao, the Comm ESCR noted there is an insufficient level of resources allocated by the Philippines to finance school facilities and qualified teachers, as well as to ensure the effective enjoyment of the right to free primary and secondary education

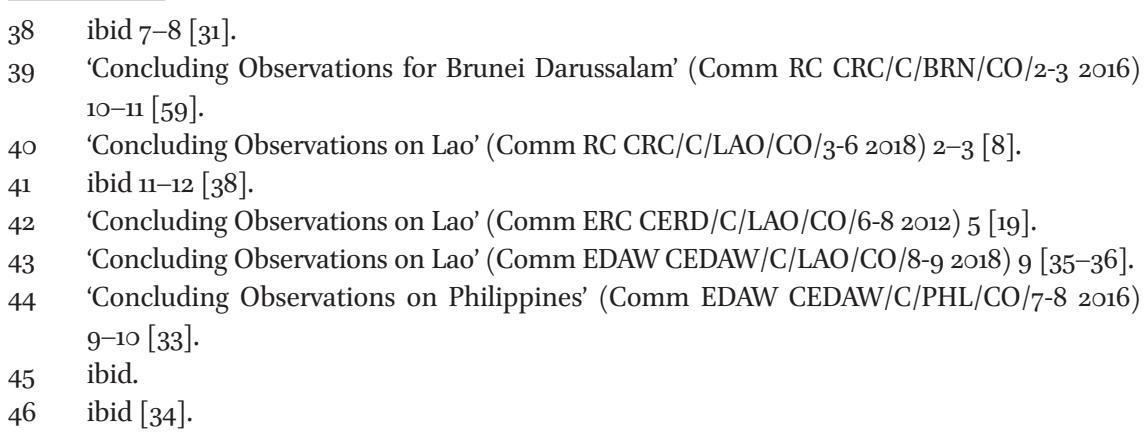


for all. ${ }^{47}$ The Comm ESCR recommended the Philippines strengthen its public education sector, by increasing the budget allocated to primary and secondary education, monitoring all schools including low-cost private schools to ensure children obtain quality education, and taking measures to assure that disadvantaged, marginalised and children with disabilities obtain quality education. ${ }^{48}$ The Comm ESCR recommendation was reiterated by the Comm RPD: the Philippines should provide access to quality education for children with disabilities. ${ }^{49}$

In relation to Cambodia, the Comm ESCR noted with concern in its Concluding Observations that primary education is not yet compulsory and emphasised that minority languages need to be taught to preserve indigenous culture of minority groups. It also recommended that Cambodia extend the coverage of the Education Law to all Cambodian children whose first language is not Khmer to protect their right to education..$^{50}$ Inadequate salaries and incentives for teachers also became the focus of the Comm ESCR in its recommendation: the Comm ESCR recommended Cambodia to increase salaries and incentives for teachers in order to ensure their professionalism. ${ }^{51}$ The Comm EDAW noted with concern the high illiteracy rates among women, especially women in rural areas, women belonging to minority groups or disabled women. ${ }^{52}$ It also noted the high disparity in school enrollment rates betwen males and females and the high drop-out rates for girls. ${ }^{53}$

The problem of gender segregation in education is apparent in Cambodia. ${ }^{54}$ The Comm EDAw strongly recommended Cambodia place a high priority on the reduction of illiteracy rates for women, specifically the marginalised and vulnerable groups, and take necessary measures to eliminate the high disparity in school enrollment rates. ${ }^{55}$ The Comm EDAw also stressed the achievement of universal primary education for girls is essential to comply with Article 10 of the CEDAW. ${ }^{56}$ The Comm ERD shared similar concerns with the Comm ESCR

47 'Concluding Observations on Philippines' (Comm ESCR E/C.12/PHL/CO/5-6 2016) 13 [55].

48 ibid [56].

49 'Concluding Observations on Philippines' (Comm RPD CRPD/C/PHL/CO/1 2018) 9-10 [40].

50 'Concluding Observationss on Cambodia' (Comm ESCR E/C.12/KHM/CO/1 2009) 11-12 [34].

$5^{1}$ ibid, [35].

52 'Concluding Observations on Cambodia' (Comm EDAW CEDAW/C/KHM/CO/3 2006) 4-5 [25].

53 ibid.

54 ibid.

55 ibid.

56 ibid. 
and the Comm EDAw about the realisation of the right to education especially for indigenous minority groups in Cambodia. ${ }^{57}$

For Myanmar, the Comm EDAW concluded that there are discriminatory problems, such as the requirement for women to attain specific grades to enroll in certain traditionally male-dominated courses, the lack of an adequate budget for the education sector and low literacy among women. ${ }^{58}$ The Comm RC, echoing similar observations made of other ASEAN member states, highlighted the issue of allocation of resources by the Government of Myanmar. ${ }^{59}$ It recommended the government increase spending on education, provide transparency in the budgetary process and adopt a budget for children's rights. ${ }^{60}$ The Comm RC also recommended that the Government of Myanmar take legislative action to further regulate the education sector to ensure access and availability of education to children in the country. ${ }^{61}$

In relation to Viet Nam, the Comm EDAW concluded the government needed to develop a monitoring and evaluation framework for the implementation of the education sector action plan, supported by a sufficient national budget. ${ }^{62}$ The Comm ERD and Comm ESCR shared the same concern with the Comm EDAW with regard to access to education for female ethnic minorities as they showed high illiteracy rates. ${ }^{63}$ The Comm ESCR urged the Government of Viet Nam to adequately plan educational personnel needs, increase investment in the education sector and improve the system to track student drop-out rates. ${ }^{64}$ The Comm RC recommended that the government increase the level of financial resources allocated for the realisation of the right to education. ${ }^{65}$

Lastly, with regard to the Government of Thailand, the Comm EDAw remained concerned with the problem of gender segregation in higher education. ${ }^{66}$ The Comm RC, in a similar fashion, highlighted the problem of resource

\footnotetext{
57 'Concluding Observations on Cambodia' (Comm ERD CERD/C/KHM/CO/8-13 2010) 4-5 [20].

58 'Concluding Observations on Myanmar' (Comm EDAW CEDAW/C/MMR/CO/4-5 2016) 11 [34-35].

59 'Concluding Observations on Myanmar' (Comm RC CRC/C/MMR/CO/3-4 2012) 4 [17-18].

60 ibid.

61 ibid, $15^{-17}\left[73^{-76}\right]$.

62 'Concluding Observations on Viet Nam' (Comm EDAW CEDAW/C/VNM/7-8 2015) 8 [26-27].

63 'Concluding Observations on Viet Nam' (Comm ERD CERD/C/VNM/10-14 2012) 4 [14]; 'Concluding Observations on Viet Nam' (Comm ESCR E/C.12/VNM/CO/2-4 2014) 10 [32].

64 ibid.

65 'Concluding Observations on Viet Nam' (Comm RC CRC/C/VNM/CO/3-4 2012) 17-18 [17-18, 67-68].

66 'Concluding Observations on Thailand' (Comm EDAW CEDAW/C/THA/CO/6-7 2017) 10-11 [34-35].
} 
allocation, due to the low percentage of the national budget allocated to the education sector. ${ }^{67}$ The Comm RC also recommended that the Government of Thailand to take policy measures to ensure every child has access to holistic early childhood development, provide educational opportunities for children who are out of school, conduct a comprehensive study to assess the causes of drop-outs, and encourage children to continue their education. ${ }^{68}$ The Comm RPD believed that the right to inclusive education remains unfulfilled in Thailand because some schools refused to admit students with disabilities. ${ }^{69}$ The Comm ESCR expressed concerns with the access and quality of education, especially the lack of free basic primary education..$^{70}$

Based on the Concluding Observations of the human rights treaty bodies, all ASEAN member states are still struggling to respect, protect and fulfill the right to education to varying degrees. This research also shows that some specific groups are considered the most vulnerable and marginalised: non-nationals, children with disabilities, LGBTQ (lesbian, gay, bisexual, transgender and queer or questioning) children, children of indigenous communities and children of minority religions. These groups were highlighted by the international human rights bodies as groups that need to be included in the human rights programmes of the member states. The member states have not successfully included the realisation of the right to education of these groups into their human rights programmes. On the positive side, each member state has made progress. However, the right to education remains a challenge for all ASEAN member states. Thus, there is a palpable demand for the AICHR and ACWC to contribute to improving the right to education of the people in ASEAN member states.

The AICHR and ACWC, A Binary Human Rights Institution? Similarities and Differences

The United Nations General Assembly Resolution 32/127 of 1977 encouraged regional organisations to develop regional human rights systems to protect human rights. A regional human rights system is important to influence a state's behaviour and the human rights agenda in a region. Subsequently, after

\footnotetext{
67 'Concluding Observations on Thailand' (Comm RC CRC/C/THA/CP/3-4 2012) 4-5 [19-20].

68 ibid $14-15$ [68].

69 'Concluding Observations on Thailand' (Comm RPD CRPD/C/THA/CO/1 2016) 7-8 [45-46].

70 'Concluding Observations on Thailand' (Comm ESCR E/C.12/THA/CO/1-2 2015), 9-10 [33-35].
} 
the formulation of the ASEAN Charter in $2007,{ }^{71}$ ASEAN took a further step in regionalisation in the Bali Concord II and III by promising that in 2020, there would be an ASEAN Community. In 2015, five years before the deadline, the ASEAN Community was formed and met in the Philippines for the first time. ${ }^{72}$

As Archarya argues, based on a conversation with Marty Natalegawa, an Indonesia diplomat, democracy in one state can affect the formulation of regional human rights organs: after the democratisation process, Indonesia pushed forward the formulation of the AICHR and recognised democracy and human rights as the foundation for the ASEAN Political-Security Community (APSC). ${ }^{73}$ To further protect the rights of women and children, ACWC was created under the ASEAN Socio-Cultural Community (ASCC) in $2010 .{ }^{74}$

The ASEAn Human Rights Declaration affirms the continuation of a singular vision of human rights from the UDHR. ${ }^{75}$ This is reflected in Article 7 but with sensitivity to the unique circumstances of ASEAN nations:

All human rights are universal, indivisible, interdependent and interrelated. All human rights and fundamental freedoms in this Declaration must be treated in a fair and equal manner, on the same footing and with the same emphasis. At the same time, the realisation of human rights must be considered in the regional and national context bearing in mind different political, economic, legal, social, cultural, historical and religious backgrounds. ${ }^{76}$

The ASEAn Human Rights Declaration also emphasises every person has human rights responsibilities towards all other individuals. ${ }^{77}$ Article 8 states:

The human rights and fundamental freedoms of every person shall be exercised with due regard to the human rights and fundamental freedoms

Article 14 of the ASEAN Charter mandated ASEAN establish an ASEAN human rights body and this body would be governed by the terms of reference determined by the ASEAN foreign ministers. ASEAN Charter (entered into force 15 December 2008) 2624 UNTS 233 <asean.org/storage/images/archive/publications/ASEAN-Charter.pdf> accessed 3 October 2020 .

Rodolfo C Severino, Southeast Asia in Search of An ASEAN Community: Insights from the Former ASEAN Secretary-General (Institute of South East Asian Studies 2006) 342-368. Acharya (n 17).

74 ibid.

75 ibid.

76 Preamble of ASEAN Human Rights Declaration, art 10; ASEAn Human Rights Declaration 2012, art 26 . 
of others. The exercise of human rights and fundamental freedoms shall be subject only to such limitations as are determined by law solely for the purpose of securing due recognition for the human rights and fundamental freedoms of others, and to meet the just requirements of national security, public order, public health, public safety, public morality, as well as the general welfare of the peoples in a democratic society. ${ }^{78}$

The progressive nature of positive human rights obligations in economic, social and cultural rights is emphasised in Article 34:

ASEAN Member States may determine the extent to which they would guarantee the economic, social and cultural rights found in this Declaration to non-nationals, with due regard to human rights and the organization and resources of their respective national economies. ${ }^{79}$

The term 'human rights' was mentioned in point 4 of the Preamble of the ASEAN Community Vision 2025:

We resolve to consolidate our Community, building upon and deepening the integration process to realise a rule-based, people-oriented, people-centred ASEAN Community, where our peoples enjoy human rights and fundamental freedoms, higher quality of life and the benefits of community building, reinforcing our sense of togetherness and common identity, guided by the purposes and principles of the ASEAN Charter. ${ }^{80}$

The Vientiane Action Programme (VAP) was created to prepare for theASEAN Community. Human rights are central to the conceptions of both the APSC and ASCC. ${ }^{81}$ Appendix 2 compares the APSC and ASCC in terms of strategies for implementing rights.

Though human rights were not elaborated comprehensively in the VAP, this was still considered progress because human rights were not the main priority of ASEAN Member States when it was formulated in $1967 .{ }^{82}$ It could be argued that the VAP put the right to education implicitly in its socio-cultural program. The

78 ibid. It is considered progressive due to the wording 'the general welfare of the peoples in a democratic society', with regard to Myanmar as a non-democratic country at the time.

79 ibid art 34.

80 'ASEAN Community Vision 2025' (2015).

81 Atillo Pisanò, 'Towards An ASEAn Human Rights Mechanism: the ASEAN Commission on the Promotion and Protection of the Rights of Women and Children' (2016) 20 Int'l J Hum Rts 3, 321-342.

82 Gorawut Numnak et al, 'The Unfinished Business: The ASEAN Inter-governmental Commission on Human Rights' (2009) Friedrich Naumann Stiftung 1-19. 
ASEAN Community Blueprint 2025 is a promising document in setting human rights targets and strategies, but its operative clauses are still vague. There are no operational clauses that will give assurance to the protection and fulfillment of human rights, specifically the right to education, which will be implemented in the ASEAN way. It is a missed opportunity as the ASEAN Community Blueprint 2025 could have been used to further explain, elaborate and specify the human rights measures that should be taken by the ASEAN member states.

Appendix 3 compares the visions, institutional promises, mandates concerning human rights, implementation mechanism and review mechanism of the APSC and ASCC. As shown in this appendix, APSC and ASCC have similar institutional designs. Both see the protection of human rights as part of their objectives, but the ASCC has more complex visions, institutional promises and actions for human rights. The intersection between the human rights mandates of the APSC and ASCC is that both communities aim to protect, fulfill and respect human rights. With regard to strategies for human rights, the ASCC formulates comprehensive concrete steps to fulfill the right to education under the ASEAN Human Rights Declaration. The implementation, review and evaluation mechanisms of the APSC and ASCC are similar: both communities have their own councils and focus on the cooperation between stakeholders to achieve the objectives of their respective blueprints. The Ascc has a distinct feature for review and evaluation specifically concerning the authority to establish a compliance monitoring system for the implementation of all ASEAN Declarations relevant to the ASCc pillar. ${ }^{83}$ This distinct feature can be used for purposes of institutional activism for the realisation of the right to education because there is a top-down compliance mechanism in the ASCC system which can be improved further as the genesis of stronger human rights promotion and protection mandates.

The APSC has the AICHR as the overarching human rights body in ASEAN and the ASCC has the ACWC as the human rights body with a specific mandate in the realm of women and children's rights. The similarities and differences between the AICHR and the ACWC are shown in Appendix 4.

With regard to the relationship with other human rights bodies within ASEAn, Article 6.8 of the Terms of Reference (TOR) of the AICHR states the AICHR is the overarching human rights institution with overall responsibility for the promotion and protection of human rights in ASEAN. ${ }^{84}$ According

83 ASEAN Socio-Cultural Community Blueprint 2025 (2015) [42] <asean.org/storage/2016/o1/ ASCC-Blueprint-2025.pdf> accessed 3 October 2020.

84 ASEAN Intergovernmental Commission on Human Rights, 'Terms of Reference' (ASEAN 2009) 11 <www.asean.org/storage/images/archive/publications/TOR-of-AICHR.pdf> accessed 3 October 2020. 
to Article 6.9, the AICHR shall work with all ASEAN sectoral bodies dealing with human rights to expeditiously determine the modalities for their ultimate alignment with the AICHR. To this end, the AICHR shall closely consult, coordinate and collaborate with such bodies in order to promote synergy and coherence in ASEAN 's promotion and protection of human rights. ${ }^{85}$ Article 7.7 of the TOR of the ACWC regulates the relationship between the AICHR and ACWC. ${ }^{86}$ The ACWC shall coordinate with the AICHR and other relevant ASEAN sectoral bodies dealing with issues pertaining to women and children, including consultations on the ultimate alignment between the ACWC and the AICHR as the overarching human rights institution in ASEAN. ${ }^{87}$ Both bodies have the consultative status and shall convene, at the minimum, two regular meetings per year. ${ }^{88}$ However, the main difference between the AICHR and ACWC is the AICHR is designated as the overarching regional human rights institution and is hierarchically superior to the ACWC. In terms of specialisation, the ACWC has a more specific mandate concerning cooperation only limited to the Comm RC and the Comm EDAW. The ACWC also has a strong mandate and authority to advocate on behalf of women and children, especially the most vulnerable and marginalised, as set out in Article $5.4^{89}$

The AICHR and ACWC: Challenges and Opportunities for the Right to Education in ASEAN

The promises and hopes of the ASEAN Human Rights Declaration that human rights are pivotal for the people of ASEAN have to be transformed into action by all ASEAN member states. As illustrated in the theme of ASEAN 2010, "Towards the ASEAN Community: From Vision to Action," it is time for action. ${ }^{90}$ Since

85 ibid.

86 ASEAN Commission on the Promotion and Protection of the Rights of Women and Children, 'Terms of Reference' (ASEAN 2010) 14 <acwc.asean.org/wp-content/uploads/2016/o4/TORACWC.pdf $>$ accessed 3 October 2020 .

87 ibid 14.

88 ibid 13 .

89 ibid.

9o Speech by HE Prime Minister Nguyen Tandung at the Inauguration of the ASEAN Commission on Promotion and Protection of the Rights of Women and Children (ACWC), Han Noi, 7 April 2010 <asean.org/?static_post=speech-by-he-prime-minister-nguyen-tandung-at-the-inauguration-of-the-asean-commission-on-promotion-and-protection-of-therights-of-women-and-children-acwc > accessed 3 October 2020 . 
2016, The AICHR has published three annual reports from 2016 to 2018, mentioning several activities related to the right to education:

1. The AICHR regional Dialogue on Mainstreaming of the Right to Education in the ASEan Community in Phnom Penh, Cambodia, 10-12 November 2017.91 The dialogue aimed to raise awareness of the right to education as a cross-cutting issue in ASEAN, garner inputs from ASEAN sectoral bodies and stakeholders to mainstream the right to education across the three community pillars of ASEAN and create a platform to strengthen regional cooperation on human rights. ${ }^{92}$

2. The AICHR Regional Workshop on Enhanced Access to Education for Children with Disabilities in Da Nang, Viet Nam, 13-14 December 2017.93 The workshop aimed to review existing problems in meeting the education needs of children with disabilities within the ASEAN region in order to establish a common understanding among ASEAN countries, raise awareness of education for children with disabilities as a cross-cutting issue in ASEAN, share experiences and best practices within and beyond ASEAN on regional governance to enhance access to education for children with disabilities and make recommendations on how to promote cooperation among relevant ASEAN bodies and stakeholders in promoting access to education for children with disabilities. ${ }^{94}$

3. The First Coordination Meeting for the Thematic Study on the Right to Education Promotion of Access to Tertiary Education in ASEAN in Vientiane, Lao, 9 April 2018. ${ }^{95}$ The meeting aimed to identify challenges faced in the areas of access to tertiary education in ASEAN and share lessons and good practices of ASEAN Member States in promoting access to tertiary education. ${ }^{96}$

The AICHR also conducted regional workshops, thematic studies and youth debates. ${ }^{97}$ However, those activities were not translated further into soft law, let alone, hard law. This is a problem because, in the matter of human rights

91 'The ASEAN Intergovernmental Commission on Human Rights (AICHR) Annual Report' (2018) 7 .

92 ibid.

93 ibid 8 .

94 ibid.

95 ibid 9.

96 ibid.

97 AICHR activities in 2015-2016 are: 1). The AIC HR Programme on Human Rights: Training of the Trainers for Journalists in ASEAN Member States, Bangkok, Thailand, 25-29 July 2015; 2). The 2nd AICHR Youth Debates on Human Rights, Singapore, 5-6 September 2015; 3). The AICHR Workshop on the Development of ASEAN Legal Instruments on Human Rights, Manila, Philippines, 14-15 September 2015; 4). The AICHR workshop on the Implementation of Human Rights Obligations Relating to the Environment and Climate Change, Mandalay, 
protection, it is important for the regional human rights institution to produce legal documents, binding instruments essential to building understanding and cooperation between the member states concerning the human rights vision and mission in ASEAN.

Myanmar, 26-27 September 2015; 5). The AICHR Regional Workshop on the Role of Youth in Promoting Human Rights in ASEAN: Making Rights a Reality, Kuala Lumpur, Malaysia, 30-31 October 2015; 6). The AICHR-SOMTC Joint Workshop on "Human Rights -based Approach to Combat Trafficking in Persons, Especially Women and Children, Yogyakarta, Indonesia, 5-6 November 2015; 7). The AICHR Regional Dialogue on the Mainstreaming of the Rights of Persons with Disabilities, Thailand, 1-3 December 2015; 8). Workshop on Transition between the AICHR Representatives 2013-2015 and AICHR Representatives 2016-2018, Vientiane, Lao, 3 February 2016; 9). The AICHR Regional Forum on Media and Human Rights in ASEAN, Malaysia, 16-17 May 2016; 10). The AICHR Workshop on Effective Communition Strategies to Combat Trafficking in Persons, Nha Trang, Viet Nam, 23-24 June 2016; 10). The 2nd AICHR Regional Dialogue on the Mainstreaming of the Rights of Persons with Disabilities in the ASEAN Community, Chiang Mai, Thailand, 29 June-1 July 2016. The AICHR, The ASEAN Intergovernmental Commission on Human Rights Annual Report 2016, July 2015-June 2016 (3 July 2016) 5-9. Based on the Annual Report of 2017, the activities of AICHR are, 1). Panel Discussion: Socialisation of the ASEAN Convention Against Trafficking in Persons, Especially for Women and Children (ACTIP) Focusing on Sharing of Good Practices on Anti-Trafficking Initiatives, ASEAN Secretariat, Jakarta, Indonesia, 15 August 2016; 2). AICHR Youth Debate on Human Rights 2016, Kuala Lumpur, Malaysia, 2223 September 2016; 3). AICHR-Senior Officials Meeting on Transnational Crime (sомтс) on Human Rights-Based Approach in the Implementation of ACTIP and ASEAN Plan of Action Against Trafficking in Persons, Especially Women and Children (APA), Jakarta, Indonesia, 29-30 September 2016; 4). AICHR Training Programme on the Rights of Persons with Disabilities, Bangkok, Thailand, 11-14 October 2016; 5). AICHR Seminar on Promoting CSR and Human Rights in ASEAN, Singapore, 3-4 November 2016; 6). AICHR Regional Workshop on Strengthening National Plans of Action on Trafficking in Persons to Ensure Effective Implementation of the ACTIP and APA, Phnom Penh, Cambodia, 1-2 December 2016; 7). First Meeting of the Task Force on the Mainstreaming of the Rights of Persons with Disabilities on ASEAN Community, Bangkok, Thailand, 5-6 December 2016; 8). AICHR Judicial Colloquium on the Sharing of Good Practices Regarding International Human Rights Law, Kuala Lumpur, Malaysia, 13-15 March 2017; 9). 2nd Coordination Meeting for the Thematic Study on the Right to Peace, Lao, 5 April 2017; 10). 2nd Meeting of the Task Force on the Mainstreaming of the Rights of Persons with Disabilities in the ASEAN Community, Jakarta, Indonesia, 19 April 2017; 11). 3rd AICHR regional Dialogue on the Mainstreaming of the Rights of Persons with Disabilities in the ASEAn Community (Access to Justice, Entrepreneurial Enterprises and Disaster Management), Phuket, Thailand, 19-21 June 2017; 12). 3rd Meeting of the Task Force on the Mainstreaming of the Rights of Persons with Disabilities in the ASEAN Community, Phuket, Thailand, 22-23 June 2017. The AICHR, The ASEAn Intergovernmental Commission on Human Rights Annual Report 2017, June 2016-June 2017 (11 July 2017) 16-22. In 2018, the activities of the AICHR are, 1). AICHR-ACWC Training Workshop on the UNCRC, Singapore, 13-14 July 2017; 2). AICHR Youth Debate on Human Rights 2017, Bangkok, Thailand, 4-6 September 2017; 3). AICHR Cross Sectoral Consultation on the Human Rights-based Instruments related to the Implementation of the ACTIP, Yogyakarta, Indonesia, 29-30 August 2017; 4). 2nd Workshop on the 
The AICHR has focused more on a promotion rather than protection mandate. ${ }^{98}$ Since 2016 , the AICHR has mostly dealt with problems within its own institution, inter alia, cooperation between institutions, internal guidelines and regularisation of meetings. Specifically, the issues of the right to education partially appear in the middle of the AICHR workshops, studies and debates. Though mainstreaming the right to education is already making positive progress, more impactful action must be taken in the future. The documents formulated do not specifically address the situation of particular ASEAN member states, but a thorough country assessment and reporting procedure are pivotal to provide an accurate diagnosis of a country's problem. The correct process will guarantee tailor-made policies and recommendations for steps that have to be taken by the ASEAN member states to foster the realisation of the right to education. This has to be improved over the years and the AICHR has to play the role of norm entrepreneur in soft diplomacy to convince ASEAN member states to elevate the mandate, at the minimum, to advocate for the most vulnerable and marginalised human rights victims.

Development of ASEAn Legal Human Rights Instruments, Manila, the Philippines, 13-14 September 2017; 5). Regional Consultation on the Thematic Study on legal Aid, Bangkok, Thailand, 11-12 October 2017; 6). AICHR 's Regional Consultation on the Right to Safe Drinking Water and Sanitation in ASEAN (with emphasis on rural communities), Sabah, Malaysia, 25-27 October 2017; 7). AIC HR Workshop on Rights-Based Approach to Regional Management Strategy for an Effective Environmental Impact Assessment (EIA), Yangon, Myanmar, 29-30 October 2017; 8). AICHR Regional Dialogue on Mainstreaming of the Right to Education in the ASEan Community, Phnom Penh, Cambodia, 10-12 November 2017; 9). AICHR Training Programme on Business and Human Rights, Bangkok, Thailand, 13-16 November 2017; 10). 5 O Years of ASEAN and 5 Years of ASEAN Human Rights Declarations Roundtable Discussion: The AICHR 's Role and Work in Fulfilling the Goals and Aspirations of AHRD 2012, Bohol, Philippines, 28 November 2017; 11). The AICHR Regional Workshop on Enhanced Access to Education for Children with Disabilities, Da Nang, Viet Nam, 13-14 December 2017; 12). 4th Meeting of the Task Force on the Mainstreaming of the Rights of Persons with Disabilities in the ASEAN Community, Da Nang, Viet Nam, 15-16 December

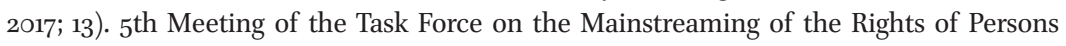
with Disabilities in the ASEAN Community, Jakarta, Indonesia, 5-6 February 2018; 14). First Cooordination Meeting for the Thematic Study on the Right to Education: Promotion of Access to Tertiary Education in ASEAN, Vientiane, Lao, 9 April 2018; 15). AICHR High Level Dialogue on Managing Freedom of Expression in the Information Age, Medan, Indonesia, 11-12 April 2018; 16). 6th Task Force Meeting on the Mainstreaming of the Rights of Persons with Disabilities in the ASEAN Community, 16-17 April 2018, Jakarta, Indonesia. AICHR, The ASEAN Intergovernmental Commission on Human Rights Annual Report 2018, July 2017-June 2018 (31 July 2018) 5-9.

98 'Have They Passed the Litmus Test?: A Report on the Performance of the ASEAN Human Rights Mechanism in 2016' (Asia Forum for Human Rights, 2017) 16 <www.forum-asia.org/ uploads/wp/2017/12/Performance-Report-AICHR-2016-FORUM-ASIA-2.pdf> accessed 3 October $202 \mathrm{O}$. 
A similar situation also occurred in the ACWC. Since 2010, the ACWC has managed to create two recommendations: the Recommendations of the Regional Workshop on Promoting the Right to a Nationality for Women and Children in the Implementation of CEDAW and CRC in ASEAN: ACWC-UNHCR Potential Partnership (19 August 2013) and the Recommendations of the Regional Workshop on Promoting the Rights of ASEAN Women and Children through Effective Implementation of the Common Issues in CEDAW and CRC Concluding Observations with Focus on Girl Child (20-22 August 2013). ${ }^{99}$ The ACWC has made several statements concerning women and children's rights issues: Joint Statement of The Fifth ASEAN Plus Three Ministerial Meeting on Social Welfare and Development (5 th AMMSWD+3), Joint Statement of The Ninth ASEAN Ministerial Meeting on Social Welfare and Development (9th AMMSWD) "Strengthening Social Welfare Development in Pursuing ASEAN Community Vision 2015" (29 September 2016), the Statement of the ASEAN Commission on the Promotion and Protection of the Rights of Women and Children (ACWC) on the Support to the High Time Movement, the Joint Statement of the ASEAN Commission on the Promotion and Protection of the Rights of Women and Children and the Special Representative of the UN Secretary-General on Violence against Children (17 January 2012). ${ }^{100}$ However, those documents do not specifically address the problems and solutions for the realisation and protection of the right to education.

The other relevant documents concerning the protection of women and children from ASEAN are the ASEAN Guidelines for a Non-Violent Approach to Nurture, Care and Development of Children in All Settings, the ASEAN Early Childhood Care, Development and Education Quality Standards, Regional Review on Laws, Policies, and Practices within ASEAN Relating to the Identification, Management and Treatment of Victims of Trafficking, Especially Women and Children, Gender Sensitive Guideline for Handling

Available at: <asean.org/wp-content/uploads/images/2013/socio_cultural/acwc/ Recommendations\%20Workshop\%20on\%2oRight\%20of\%2oNationality_FINAL. pdf> accessed 3 October 2020; and <asean.org/wp-content/uploads/images/2013/ socio_cultural/acwc/Recommendations_Workshop\%2oon\%2oCEDAW\%2oCRC\%20 Common\%2oIssues_FINAL.pdf $>$ accessed 3 October 2020.

Available at: <asean.org/joint-statement-of-the-fifth-asean-plus-three-ministerialmeeting-on-social-welfare-and-development-5th-ammswd $3 />$ accessed 3 October 2020; <asean.org/storage/2016/10/5-Joint-Statement-9th-AMMSWD_agreed-atAMMSWD-meeting.pdf> accessed 3 October 2020; <https://www.asean.org/wp-content/ uploads/2016/02/Statement-of-the-ACWC_FINAL.pdf> accessed 3 October 2020; and <asean.org/joint-statement-of-the-asean-commission-on-the-promotion-and-protectionof-the-rights-of-women-and-children-acwc-and-the-special-representative-of-the-unsecretary-general-on-violence-against-children/> accessed 3 October 2020. 
Women Victims of Trafficking in Persons, the ASEan Regional Plan of Action on the Elimination of Violence against Children (ASEAN RPA on EVAC), and the ASEAN Regional Plan of Action on the Elimination of Violence against Women (ASEAN RPA on EVAW). ${ }^{101}$ The ASEAN guidelines are not legal instruments. Thus, there is no legal impact if member states do not implement those guidelines.

The existence of the stronger intsitutions, the AICHR and ACWC, should have strengthened the universal values of human rights and brought ASEAN closer to its fellow regional and international human rights institutions. The ASEAN Annual Report 2017-2018 stated that ASEAN demonstrated care for the needs of out-of-school children and youths by establishing the ASEAN Declaration on Strengthening Education for Out-of-School Children and Youth (ooscy) with programmes for regional advocacy and the development of equivalency frameworks for basic education. ${ }^{102}$ ASEAN always prioritises a soft approach for dealing with problems. This is consistent with the principles of non-intervention in ASEAN and respect for each member state's sovereignty as elaborated in the APSC and ASCC blueprints. ${ }^{103}$ This theory is evidenced by the wordings from many ASEAN documents: the wordings are not mandatory in nature (inter alia, "encourage", "suggest", "recommend") and are limited to the promotion of human rights. The other indicator is the absence of a time limit for the recommendations and tangible responses from the AICHR and ACWC if the recommendations are not implemented by the member state. When it comes to human rights obligations, clear and authoritative positivistic words are needed because human rights are always a product of struggle. The member states urgently need to decide the human rights minimum core obligations to ensure there is a reasonable standard of assessment for the implementation and realisation of human rights in ASEAN.

Human rights obligations and standards become clearer in the 21st century as compared to the period immediately after World War II. It is unwise for

101 Available at: <asean.org/wp-content/uploads/2017/o3/ASEAN-Guideline-for-NonViolent-Approach_FINAL.pdf> accessed 3 October 2020; <asean.org/wp-content/ uploads/2017/03/ASEAN-ECCDE-Quality-Standards-Final.pdf> accessed 3 October 2020; $<$ www.asean.org/wp-content/uploads/2012/o5/Final-ASEAN-RPA-on-EVAC-IJP-16.o3.20162nd-Reprint-updated-ISBN-24.03.....pdf> accessed 3 October 202O; and <asean.org/ wp-content/uploads/2012/o5/FAASN_gender_8_email_REV.pdf> accessed 3 October 2020. 'ASEAN Annual Report 2017-2018: A Resilient and Innovative ASEAN Community' (ASEAN 2018) 26 <asean.org/wp-content/uploads/2018/o8/ASEAN-Annual-Report-2017-2018.pdf> accessed 3 October 2020 .

103 Lee Jones, ASEAN, Souvereignty and Intervention in Southeast Asia (Palgrave Macmillan 2012) 211; Rodolfo C Severino, ASEAN (Institute of Asian Studies 2008) 58. 
those who are in favour of human rights relativism to assume human rights obligations and standards are vague, relative and depend on the full discretion of each member state. Such assumptions also do not conform with the reality that in other regional systems human rights are enforceable in a court. Deliberative human rights scholars believe human rights law is a persuasive mechanism to promote human rights. ${ }^{104}$ Merry believes the human rights legal system produces a culture and understanding of human rights in various societies. ${ }^{105}$ Bui addressed the lack of a strong mandate behind the ASEAN human rights mechanism and proposed the idea of an ASEAN human rights court and amendments to the current system. ${ }^{106}$ Though I largely agree with Bui's ideas, I also believe organic changes need to be taken before progressing further to the establishment of an ASEAN human rights court as the final goal of an ASEAN human rights mechanism. ${ }^{107}$ Institutional reforms are needed as preparatory steps for the establishment of an ASEAN human rights court. The institutional reforms can be explained in the following step by step narrative.

The first step is the elimination of overlapping subjects of operations between those bodies. The problem of overlapping subjects of monitoring is palpable between ASEAN human rights institutions. The AICHR and the ACWC have intersecting mandates on the right to education, especially the ACWC 's focus on women and children's rights. This problem needs to be settled before strengthening the mandates of both organs in order to ensure certainty of the mandates to guarantee their respective effectiveness. There are two options to eliminate the overlapping mandates; to merge the ACWC together with the AICHR or to draw new terms of references for both bodies to provide a clear barrier between mandates. For instance, the ACWC can take a more specialised approach to handle the problem of the most vulnerable and marginalised communities (non-nationals, LG BTQ children, children from indigenous communities and children of minority religions) and the AICHR can focus on general human rights issues. Too many institutions with overlapping mandates will impede the realisation of the right to education. The reorganisation by merging the institutions or drawing clear and imperative mandates is a condition sine qua non for the realisation of the right to education in ASEAN.

\footnotetext{
104 Marie-Bénédicte Dembour, 'What Are Human Rights? Four Schools of Thought' (2010) 32 HRQ 1, 1-20.

105 ibid.

106 Hien Bui, 'The ASEan Human Rights System: A Critical Analysis' (2016) 11 Asian J Comp L 1, 111-140.

107 ibid.
} 
The second step is to strengthen the mandates of the AICHR and ACWC. The mandates and authority of both organs are limited to consultative power. ${ }^{108}$ Both have no authority to investigate, inquire or make and enforce binding decisions. ${ }^{109}$ Based on historical records, human rights are products of struggle. They have to be enforced in order to make them a reality. The nature of legal protection is its certainty and clear wordings to limit obscuur libel situations. The realisation of the right to education will be more effective if the AICHR and ACWC have more authority in a form of quasi-legal authority to enforce the ASEAN member states' human rights obligations within the framework of a protection mandate.

The third step is an assurance that the AICHR and ACWC will work coherently with the other international human rights bodies. Based on the contextualisation of the right to education in ASEAN member states, the AICHR and ACWC should take further steps to accelerate respect, protection and fulfillment of the right to education in ASEAN by taking into its highest consideration the Concluding Observations of international human rights bodies. As outlined earlier in this article, various international human rights bodies identified similar problems with regard to the implementation and realisation of the right to education in ASEAN member states. This pattern is a description of the problematic situation in the realm of the right to education. ${ }^{110}$ As a solution to this problem, by utilising the AICHR and ACWC, the ASEAN member states must deliberate on the importance of ensuring the mandates of both organs include enforcement powers rather than merely consultative powers.

The fourth step is the prioritisation of institutional reforms in the AICHR, ACWC and ASEAN member states. The AICHR and ACWC have been focusing their works in organising thematic discussions, workshops and debates with regard to crucial issues in the realm of human rights. However, discussions on institutional reforms have never been conducted together by those actors, although this step is important to build understanding between actors in this case. This step is realistic because the nature of thematic discussions, workshops and debates is to foster deliberative talks and should have been done continuously. This approach aims to gradually increase the understandings of the actors that it is important for human rights bodies to have independent power not only limited to promotion and protection mandates. This step also fits with the

108 Michelle Staggs Kelsall, 'The New Intergovernmental Commission on Human Rights: A Toothless Tiger or Tentative Step' (2009) Asia Pacific Issues, Analysis from the East-West Center No. 9o, 1-8.

109 ibid.

110 'Education Systems in ASEAN+6 Countries: A Comparative Analysis of Selected Educational Issues', (UNESCO 2014) 8. 
current mandates of the AICHR and ACWC in terms of human rights promotion. Through the lens of the separation of powers, there will be no checks and balances between actors if the AICHR and ACWC do not have the power to conduct an independent assessment of the member states' human rights performance; thus building a gradual understanding of this reform is pivotal.

From the constructivist school, both the AICHR and ACWC have the potential to become norm entrepreneurs in human rights. ${ }^{111}$ The AICHR and ACWC shall cultivate and promote ASEAN human rights to universalise the idea of universal human rights. In comparison with other regions, inter alia, the Council of Europe and OAs which have progressed to the accountability of human rights in regional human rights courts, ASEAN is left behind by not having an ASEAN human rights treaty or strong human rights institution. ${ }^{112}$ Human rights conformity must respect the cultural values of the region. The ASEAN human rights system shall enhance the idea of universal human rights; though geographically different, all regions share the same fundamental values of human dignity and worth. ${ }^{113}$ Regional human rights institutions should have supplemented the national human rights institutions and also become a strategic norm entrepreneur to foster the creation of a regional human rights treaty. ${ }^{114}$ To be able to make progress, a robust and clearer protection mandate is needed to ensure that the AICHR and ACWC can take independent action to protect and promote human rights to the ASEAN member states.

Based on the analysis of the Concluding Observations from the international human rights organs, the realisation of the right to education in ASEAN is

111 Matthew Davies, 'Explaining the Vientiane Action Programme: ASEAN and the Institutionalisation of Human Rights' (2013) 26 The Pacific Review 4, 385-406; Hiro Katsumata, ASEAN's Cooperative Security Enterprise: Norms and Interests in the ASEAN Regional Forum (Palgrave Macmillan 2009) 53.

112 Tan Hsien-Li, The ASEAN Inter-Governmental Commission on Human Rights, Institutionalising Human Rights in Southeast Asia (CUP 2011) 2-3; Laura Allison, The EU, ASEAN and Interregionalism, Regionalism Support and Norm Diffusion Between the EU and ASEAN (Palgrave Macmillan 2015) 63-64.

113 Robin Ramcharan and James Gomez, 'The Protection of Human Rights in Southeast Asia: Improving the Effectiveness of Civil Society' (2013) 13 APJHRL 2, 27-43.

114 Vitit Muntarbhorn, 'Development of the ASEAN human rights mechanisms: Briefing Paper requested by the Directorate-General for External Policies of the European Union' (2012) Directorate-General for External Policies of the Union (European Parliament), Brussels, Expo/B/Droi/2012/05, 6 . 
hampered due to several problems, inter alia, low allocation of resources in the education sector, discrimination towards girls, minority and indigenous groups and limited access to quality education in rural areas. Cultural norms also become barriers when it comes to the realisation of the right to education as can be seen in the case of education for women and minority groups. The lack of inclusive educational programmes is caused by the cultural understanding in a patriarchal society that women are not entitled to education on the same level as men. In many documents, the right to education of minorities are not well elaborated and, even worse, not mentioned at all in country reports. The irony is even a country with high-quality education like Singapore does not afford accurate, scientific and up-to-date instructions on issues faced by minority groups as shown in the country reports. The AICHR and ACWC have not touched upon the problem of cultural norms or produced tangible and effective solutions. This is evidence that the realisation of the right to education in ASEAN member states is still problematic, and more concrete action is needed for it to be taken seriously. This includes institutional reform of the human rights body to adopt a stronger mandatory power in human rights monitoring.

The role of the AICHR and ACWC can be used to foster the progress of each ASEAN member state if the protection mandate is strengthened to the extent of a quasi-legal power. Reforms in the institutional design of the AICHR and ACWC are necessary to ensure checks and balances in human rights monitoring work between the AICHR, ACWC and ASEAN member states. The authority to inquire, assess and investigate human rights problems is pivotal for the AICHR and ACWC to help member states in the realisation of the right to education and maximise its function as regional human rights organs. There is also a need to clarify the intersection of mandates between the AICHR and ACWC to eliminate the overlapping mandates between both organs. The specialisation approach can be used to direct the ACWC to focus on the most vulnerable and marginalised communities and the AICHR to focus on general human rights issues. The AICHR, ACWC and ASEAN member states must prioritise the thematic discussions, workshops and debates about institutional reforms in their works as a process of building gradual understanding to find the best institutional design for the human rights system in ASEAN. It has been decades since 1967 and to accomplish the target of the ASEAN Community, the right to education for all should be the top priority of every member state in ASEAN. The ASEAN Community has promised better respect, protection and fulfillment of human rights for the people and those promises can become a reality with the contribution of a robust regional human rights system by the AICHR and ACWC. 


\section{Appendix 1: The ASEAn Member States and Their Ratification of International Human Rights Treaties}

\begin{tabular}{|c|c|c|}
\hline Country & $\begin{array}{l}\text { International Human Rights } \\
\text { Instruments }\end{array}$ & $\begin{array}{l}\text { Date of Ratification } \\
\text { (a) accession, (s) succes }\end{array}$ \\
\hline $\begin{array}{l}\text { Brunei Darus- } \\
\text { salam } 115\end{array}$ & $\begin{array}{l}\text { 1. CEDAW (Convention on the Elimination } \\
\text { of All Forms of Discrimination Against } \\
\text { Women) } \\
\text { 2. CRC (Convention on the Rights of the } \\
\text { Child) } \\
\text { 3. CRC-OP-AC (Optional Protocol to the } \\
\text { Convention on the Rights of the Child on } \\
\text { the Involvement of Children in Armed } \\
\text { Conflict) } \\
\text { 4. CRC-OP-SC (Optional Protocol to the } \\
\text { Convention on the Rights of the Child on } \\
\text { the Sale of Children, Child Prostitution } \\
\text { and Child Pornography) } \\
\text { 5. CRPD (Convention on the Rights of } \\
\text { Persons with Disabilities) }\end{array}$ & $\begin{array}{l}\text { 1. } 24 \text { May } 2006 \text { (a) } \\
\text { 2. } 27 \text { December } 1995(\mathrm{a}) \\
\text { 3. } 17 \text { May } 2016(\mathrm{a}) \\
\text { 4. } 21 \text { November } 2006 \text { (a) } \\
\text { 5. } 11 \text { April } 2016\end{array}$ \\
\hline Cambodia $^{116}$ & $\begin{array}{l}\text { 1. CAT (Convention Against Torture) } \\
\text { 2. CAT-OP (Optional Protocol Convention } \\
\text { Against Torture) } \\
\text { 3. CCPR (International Covenant on Civil } \\
\text { and Political Rights) } \\
\text { 4. CED (Convention for the Protection of } \\
\text { All Persons from Enforced Disappearance) } \\
\text { 5. CEDAW } \\
\text { 6. CERD (International Convention on } \\
\text { the Elimination of All Forms of Racial } \\
\text { Discrimination) }\end{array}$ & $\begin{array}{l}\text { 1. } 15 \text { October } 1992 \text { (a) } \\
\text { 2. } 3 \text { O March } 2007 \\
\text { 3. } 26 \text { May } 1992 \\
\text { 4. } 27 \text { June } 2013 \text { (a) } \\
\text { 5. } 15 \text { October } 1992 \\
\text { 6. } 28 \text { November } 1983 \\
\text { 7. } 26 \text { May } 1992 \\
\text { 8. } 15 \text { October } 1992 \\
\text { 9. } 16 \text { July } 2004 \\
\text { 10. } 3 \text { O May } 2002 \\
\text { 11. } 20 \text { December } 2012\end{array}$ \\
\hline
\end{tabular}

115 Brunei Darussalam does not accept any individual complaints procedures or inquiry procedures.

116 Cambodia accepted the Optional Protocol to the Convention on the Elimination of All Forms of Discrimination Against Women on 13 October 2010 (individual complaints procedure), CAT Article 20 concerning the Inquiry Procedure under the CAT on 15 October 1992, CED Article 33 concerning the Inquiry Procedure under the International Convention for the Protection of All Persons from Enforced Disappearance on 27 June 2013, and CEDAW-OP Articles 8-9 concerning the Inquiry Procedure under the Optional 
International Human Rights

Country

Country

7. CESCR (International Covenant on Eco-
nomic, Social and Cultural Rights)
8. CRC
9. CRC-OP-AP
1O. CRC-OP-SC
11. CRPD
1. CAT
2. CCPR
3. CEDAW
4. CERD (International Convention on
the Elimination of All Forms of Racial
Discrimination)
5. CESCR
6. CMW (International Convention on the
Protection of the Rights of All Migrant
Workers and Members of Their Families)
7. CRC
8. CRC-OP-AC
9. CRC-OP-SC
10. CRPD
1. CAT
2. CCPR
3. CEDAW
4. CERD
5. CESCR
6. CRC
7. CRC-OP-AC
8. CRC-OP-SC
9. CRPD
Remocratic

Date of Ratification

(a) accession, (s) succession
1. 28 October 1998

2. 23 February 2006 (a)

3. 13 September 1984

4. 25 June 1999 (a)

5. 23 February 2006 (a)

6. 31 May 2012

7. 5 September 1990

8. 24 September 2012

9. 24 September 2012

10. 30 November 2011
1. 26 September 2012

2. 25 September 2009

3. 14 August 1981

4. 22 February 1974 (a)

5. 13 February 2007

6. 8 May 1991 (a)

7. 20 September 2006 (a)

8. 20 September 2006 (a)

9. 23 September 2009

Protocol to the Convention on the Elimination of All Forms of Discrimination Against Women on 13 October 2010.

117 Indonesia does not accept any individual complaints procedures but accepted the CAT Article 2o Inquiry Procedure on 28 October 1998.

118 Lao People's Democratic Republic does not accept any individual complaints procedures but accepted the CAT Article 20 Inquiry Procedure on 26 September 2012. 
International Human Rights

Country

Malaysia $^{119}$

Philippines $^{121}$

\author{
1. CEDAW \\ 2. CRC \\ 3. CRC-OP-AC \\ 4. CRC-OP-SC \\ 5. CRPD
}

Myanmar $^{120}$

1. CAT

1. CEDAW
2. CESCR
3. CRC
4. CRC-OP-SC
5. CRPD

2. CAT-OP

3. $\mathrm{CCPR}$

4. CCPR-OP2-DP (Second Optional Proto-

col to the International Covenant on Civil

and Political Rights aiming at the Abolition of Death Penalty)

5. CEDAW
6. CERD
7. CESCR
8. CMW
9. CRC
10. CRC-OP-AC
11. CRC-OP-SC
12. CRPD

Singapore $^{122}$

1. CEDAW

2. CERD

3. $\mathrm{CRC}$

4. CRC-OP-AC

\section{Date of Ratification}

(a) accession, (s) succession
1. 5 July 1995 (a)

2. 17 February 1995 (a)

3. 12 April 2012 (a)

4. 12 April 2012 (a)

5. 19 July 2010

1. 22 July 1997 (a)

2. 6 October 2017

3. 15 July 1991 (a)

4. 16 January 2012 (a)

5. 7 December 2011 (a)

1. 18 June 1986 (a)

2. 17 April 2012 (a)

3. 23 October 1986

4. 20 November 2007
5. 5 August 1981

6. 15 September 1967

7. 7 June 1974

8. 5 July 1995

9. 21 August 1990

10. 26 August 2003

11. 28 May 2002

12. 15 April 2008

1. 5 October 1995 (a)

2. 27 November 2017

3. 5 October 1995 (a)

4. 11 December 2008

119 Malaysia does not accept any individual complaints procedures or inquiry procedures.

120 Myanmar does not accept any individual complaints procedures or inquiry procedures.

121 The Philippines accepted two individual complaints mechanisms namely CCPR-OP1 (Optional Protocol to the International Covenant on Civil and Political Rights) on 22 August 1989 and CEDAW-OP on 12 November 2003. The Philippines also accepted two inquiry mechanisms, namely the CAT Article 2o Inquiry Procedure on 18 June 1986 and CEDAW-OP Article 8-9 on 12 November 2003.

Singapore does not any accept individual complaints procedures or inquiry procedures. 


\section{International Human Rights}

Country

\begin{tabular}{|c|c|c|}
\hline & 5. CRPD & 5. 18 July 2013 \\
\hline \multirow[t]{9}{*}{ Thailand $^{123}$} & 1. CAT & 1. 2 October $2007(\mathrm{a})$ \\
\hline & 2. CCPR & 2. 29 October $1996(a)$ \\
\hline & 3. CEDAW & 3. 9 August 1985 (a) \\
\hline & 4. CERD & 4. 28 January $2003(a)$ \\
\hline & 5. CESCR & 5. 5 September 1999 (a) \\
\hline & 6. CRC & 6. 27 March 1992 (a) \\
\hline & 7. CRC-OP-AC & 7. 27 February $2006(a)$ \\
\hline & 8. CRC-OP-SC & 8. 11 January 2006 (a) \\
\hline & 9. CRPD & 9. 29 July 2008 \\
\hline \multirow[t]{9}{*}{ Viet Nam $^{124}$} & 1. CAT & 1. 5 February 2015 \\
\hline & 2. CCPR & 2. 24 September $1982(\mathrm{a})$ \\
\hline & 3. CEDAW & 3. 17 February 1982 \\
\hline & 4. CERD & 4. 9 June 1982 (a) \\
\hline & 5. CESCR & 5. 24 September $1982(a)$ \\
\hline & 6. CRC & 6. 28 February 1990 \\
\hline & 7. CRC-OP-AC & 7. 20 December 2001 \\
\hline & 8. CRC-OP-SC & 8. 20 December 2001 \\
\hline & 9. CRPD & 9. 5 February 2015 \\
\hline
\end{tabular}

\section{Date of Ratification}

(a) accession, (s) succession

SOURCE: Office of the United Nations High Commissioner for Human Rights, "UN Treaty Body Database" <https://tbinternet.ohchr.org/_layouts/TreatyBodyExternal/Treaty.aspx?CountryID= 25\&Lang=EN $>$ accessed 3 October 2020.

123 Thailand accepted two individual complaints procedures, namely CEDAW-OP on 14 June 2000 and CRC-OP-IC (Optional Protocol to the Convention on the Rights of the Child concerning Individual Complaints) on 25 September 2012. Thailand accepted three inquiry procedures, namely the CAT Article 20 Inquiry Procedure on 2 October 2007, CEDAW-Op Article 8-9 on 14 June 2000 and CRC-OP-IC Article 13 on 25 September 2012.

124 Viet Nam does not accept any individual complaints procedures but accepted one inquiry procedure namely, CAT Article 20 on 2 May 2015. 


\section{Appendix 2: Comparison Between APSC and AsCC in Terms of Strategies}

\begin{tabular}{|c|c|c|}
\hline VAP & APSC & ASCC \\
\hline $\begin{array}{l}\text { Strategies } \\
\text { for human } \\
\text { rights }\end{array}$ & $\begin{array}{l}\text { Promoting understanding and appre- } \\
\text { ciation of member countries' per- } \\
\text { sonal identity, promotion of human } \\
\text { rights and obligations, establishment } \\
\text { of an institutional framework to } \\
\text { facilitate the free flow of information } \\
\text { among member countries, support } \\
\text { and assistance in the development } \\
\text { of rule of law and good governance } \\
\text { within each member state; increase } \\
\text { the participation of non-governmen- } \\
\text { tal organizations (NGO s); prevent } \\
\text { and combat corruption. }\end{array}$ & $\begin{array}{l}\text { Facilitating universal access to } \\
\text { education and promoting high } \\
\text { standards through networking } \\
\text { and institutional collaborations } \\
\text { and reduce social risks faced by } \\
\text { children, women, the elderly } \\
\text { and persons with disabilities, by } \\
\text { supporting programs consistent } \\
\text { with international conventions, } \\
\text { and promoting services such } \\
\text { as aged care, health care and } \\
\text { education. }\end{array}$ \\
\hline
\end{tabular}

SOURCE: 'Vientiane Action Programme' (ASEAN 2004) < https://www.asean.org/storage/images/ archive/VAP-10th\%2OASEAN\%2oSummit.pdf $>$ accessed 3 October 2020.

\section{Appendix 3: ASEAn Political-Security and ASEAN Socio-Cultural Communities' Blueprints and Focus on Human Rights}

\section{APSC}

APSC emphasised cooperation and

collaboration between Member

States to achieve a secure and har-

monious environment in the region

and also contribute collectively to

global peace.
AscC is defined as the means to engage and benefit people; its nature is inclusive, sustainable, resilient and dynamic. 
Institutional APSC focuses on the concept of a rulespromises based community that fully adheres to ASEAN fundamental principles, shared values and norms as well as principles of international law governing the peaceful conduct of relations among states.

Respect for human rights of the people and guided by the principles of democracy, good governance and the rule of law. Several distinct promises of the APSC are the peaceful dispute settlement mechanisms, free-nuclear weapons region, maritime cooperation, respect to all ASEAN institutions and contribution to global peace and security.

\section{Actions}

on Promo-

APSC actions on promotion and

tion and

Protection

of Human

\section{Rights}

ASCC also strives to be an inclusive community that promotes high quality of life, equitable access to opportunities for all and promotes and protects the human rights of women, children, youth, the elderly/older persons, persons with disabilities, migrant workers, and vulnerable and marginalised groups.

ASCC promises are directed primarily inwards for the benefit of the people of ASEAN. The promises with regard to human rights are similar to the promises of APSC.

ASCC also has promised to proactively contribute to the global community.

Education is one of the inclusive targets in the ASCC 2025 Blueprint. The operative strategic measures as formulated by ASEAN to reduce barriers are: 
i. Establish an ASEAN human rights body through the completion of its Terms of Reference (ToR) by 2009 and encourage cooperation between it and existing human rights mechanisms, as well as with other relevant international organisations;

\section{ii. Complete a stock-take of existing human rights mechanisms and equivalent bodies, including sectoral bodies promoting the rights of women and children by 2009 ;}

\section{iii. Cooperate closely with efforts of the sectoral bodies in the develop- ment of an ASEAN instrument on the protection and promotion of the rights of migrant workers;}

\section{iv. Strengthen interaction between} the network of existing human rights mechanisms as well as other civil society organisations, with relevant ASEAN sectoral bodies; i. Reduce inequality and promote equitable access to social protection and enjoyment of human rights by all and participation in societies, such as developing and implementing frameworks, guidelines and mechanisms for the elimination of all forms of discrimination, violence, exploitation, abuse and neglect;

ii. Provide guidelines for quality care and support for women, children, youths, the elderly/older persons, persons with disabilities, migrant workers, ethnic minority groups, and vulnerable and marginalised groups;

iii. Provide regional mechanisms to promote access to information and communication technologies for all;

iv. Promote regional cooperation initiatives to support ASEAN Member States in implementing the Bali Declaration on the Enhancement of the Role and Participation of Persons with Disabilities in the ASEAN Community and the ASEAn Decade of Persons with Disabilities (2011-2020); and 
v. Enhance/conduct exchange of information in the field of human rights among ASEAN countries in order to promote and protect human rights and fundamental freedoms of peoples in accordance with the ASEAN Charter and the Charter of the United Nations, and the UDHR and the Vienna Declaration and Programme of Action;

vi. Promote education and public awareness of human rights; and

vii. Cooperate closely with efforts of the sectoral bodies in the establishment of an ASEAN commission on the promotion and protection of the rights of women and children. v. Promote regional cooperation initiatives to support ASEAN Member States to be well prepared for an ageing society.

The strategic measures to provide equitable access for all, specifically in education sector are...

iv. Provide mechanisms and enhance institutional capacity to promote greater access to basic social services for all, such as health services and education including early childhood education and vocational education, skills training, and promotion of skills recognition;...

xi. Promote equitable opportunities to quality education and access to information with priority given to the advancement of universal access to education... 
The strategic measures in the field of promotion and protection of human rights are:

i. Promote regional inter-sectoral mechanisms towards a holistic and multi-disciplinary approach in enhancing quality care, well-being, gender equality, social justice, human rights and fundamental freedoms, especially the vulnerable groups, in response to all hazards and emerging social and economic risks/threats;

ii. Promote sustainable financing mechanisms for social protection, particularly universal health coverage, early childhood care and development, financial risk protection for disaster risk reduction and climate change adaptation, and social pension, through strategic partnerships with private sector and other relevant stakeholders;

iii. Provide regional platforms for dialogue and support initiatives to address issues of traditional practices that impinge upon the fulfilment of rights;

iv. support accelerated implementation among ASEAN Member States to extend coverage, accessibility, availability, comprehensiveness, quality, equality, affordability and sustainability of social services and social protection; 
v. Enhance the effective implementation of relevant ASEAN declarations and instruments related to human rights;

vi. Enhance regional initiatives and stakeholder participation to promote the elimination of all forms of discrimination-institutionalised or otherwise-exploitation, trafficking, harmful practices, and violence and abuse against children, women, persons with disabilities, youths, migrant workers, the elderly/older persons, and victims/ survivors of trafficking in persons, ethnic minority groups, and vulnerable marginalised groups;

viii. Encourage intergenerational relationships, families and communities in promoting and protecting the rights of the elderly/older persons, and providing quality care and protection of the elderly/older persons, in accordance with the Brunei Darussalam Declaration on Strengthening Family Institution: Caring for the Elderly; and

ix. Enhance regional initiatives in accordance with the ASEAN Declaration on the Protection and Promotion of the Rights of Migrant Workers to improve the protection and promotion of the rights of workers. 
APSC

Imple-

The APsc demands that Member

mentation States integrate the programmes

mechanism and activities of the APSC Blue-

print into their respective national

development plans. There is also the

demand of coordination between

all relevant ASEAN senior official

bodies which shall be responsible

for ensuring the implementation of

the various elements, actions and commitments in the Blueprint by reflecting them in their respective work plans, mobilising resources for them, raising issues for the consideration of their respective ministerial bodies and the ASEAN Leaders, and undertaking national initiatives in order to meet these commitments.

APSC created the Coordinating Conference for the APSC Plan of Action (AscCO) to serve as the platform for coordinating the efforts of various sectoral bodies through exchanges of information, best practices, and lessons learned in the implementation of the APSC Blueprint. Ascco 's new initiatives and recommendations on emerging issues shall be reported to the APSC Council. The APsc Council is responsible for the implementation and coordination between all actors in the APSC. The progress of the APSC Blueprint shall be reported annually by the Secretary-General of ASEAN to the annual ASEAN Summit, through the APsc Council.
Ascc

The implementation mechanism of AsCC Blueprint 2025 is designed to be guided by the ASEAN Charter as well as other key ASEAN instruments and documents. The Blueprint also highlights the importance of the relevant domestic laws, regulations and policies as guidance for implementation. The Ascc Council has the mandate to oversee the implementation of the Ascc Blueprint 2025. The Ascc Council is responsible for the implementation and coordination between all actors in the ASCC. 


\begin{tabular}{|c|c|c|}
\hline & APSC & Ascc \\
\hline $\begin{array}{l}\text { Review } \\
\text { mechanism }\end{array}$ & $\begin{array}{l}\text { There is a review and evaluation } \\
\text { mechanism for the implementation } \\
\text { of the APSC Blueprint. The review } \\
\text { shall be conducted biennially by the } \\
\text { ASCCO-ASEAN Secretariat. The result } \\
\text { of the review and evaluation shall be } \\
\text { reported by the Secretary-General of } \\
\text { ASEAN to the ASEAN Summit through } \\
\text { the APSC Council. }\end{array}$ & $\begin{array}{l}\text { There is a review and evaluation } \\
\text { mechanism for the implementa- } \\
\text { tion of ASCC Blueprint } 2025 \text {. ASCC } \\
\text { Blueprint provides steps for review } \\
\text { and evaluation such as the ASCC } \\
\text { Scorecard and work plan for the } \\
\text { sectoral bodies. The AScC Scorecard } \\
\text { will be used to enhance the new AsCC } \\
\text { Blueprint } 2025 \text { and its indicators. }\end{array}$ \\
\hline
\end{tabular}

SOURCE: ASEAN Community Vision 2025 (2015) <www.asean.org/wp-content/uploads/images/ 2015/November/aec-page/ASEAN-Community-Vision-2025.pdf>; ASEAN Socio-Cultural Community Blueprint 2025 (2015) <asean.org/storage/2016/o1/ASCC-Blueprint-2025.pdf>; ASEAN Political-Security Community Blueprint (2009) < asean.org/wp-content/uploads/images/ archive/5187-18.pdf>, all accessed 3 October 2020 .

\section{Appendix 4: The AICHR and ACWC Purposes, Principles and Mandates}

\section{AICHR}

Purposes "1.1 To promote and protect human rights and fundamental freedoms of the peoples of ASEAN;
ACWC

“2.1. To promote and protect the human rights and fundamental freedoms of women and children in ASEAN, taking into consideration the different historical, political, socio-cultural, religious and economic context in the region and the balances between rights and responsibilities. 
1.2. To uphold the right of the peoples of ASEAN to live in peace, dignity and prosperity;

1.3. To contribute to the realization of the purposes of ASEAN as set out in the ASEAN Charter in order to promote stability and harmony in the region, friendship and cooperation among ASEAN Member States, as well as the well-being, livelihood, welfare and participation of ASEAN peoples in the ASEAN Community building process;

\subsection{To promote human rights}

within the regional context, bearing in mind national and regional particularities and mutual respect for different historical, cultural and religious backgrounds, and taking into account the balance between rights and responsibilities;

1.5. To enhance regional cooperation with a view to complementing national and international efforts on the promotion and protection of human rights; and
2.2. To uphold, promote, protect, respect and fulfill the rights of women and children in ASEAN to live in peace, equality, justice, dignity and prosperity. 2.3. To promote the well-being, development, empowerment and participation of women and children in the ASEAN Community building process which contribute to the realization of the purposes of ASEAN as set out in the ASEAN Charter.

2.4. To enhance regional and international cooperation with a view to complementing national and international efforts on the promotion and protection of the rights of women and children.

2.5. To uphold human rights as prescribed by the Universal Declaration of Human Rights, the Vienna Declaration and Programme of Action, CEDAW, CRC, Beijing Platform for Action (B PFA), World Fit for Children, International Humanitarian Law and other international human rights instruments and regional declarations related to women's and children's rights to which ASEAN Member States are parties. 
1.6. To uphold international human rights standards as prescribed by the Universal Declaration of Human Rights, the Vienna Declaration and Programme of Action, and international human rights instruments to which ASEAN Member States are parties."

Principles “2.1. Respect for principles of ASEAN as embodied in Article 2 of the ASEAN Charter, in particular: a. Respect for the independence, sovereignty, equality, territorial integrity and national identity of all ASEAN member states;

b. Non-interference in the internal affairs of ASEAN Member States;

c. Respect for the right of every Member State to lead its national existence free from external interference, subversion and coercion; d. Adherence to the rule of law, good governance, the principles of democracy and constitutional government;

e. Respect for fundamental freedoms, the promotion and protection non-confrontational and coopof human rights, and the promotion of social justice;
2.6. To promote stability and harmony in the region, friendship and cooperation among ASEAN Member States."

“3.1. To respect for the principles of ASEAN as embodied in Article 2 of the ASEAN Charter. 3.2 To respect for human rights principles, including universality, indivisibility, interdependence and interrelatedness of all fundamental freedoms and the rights of women and children, the guiding principles of CEDAW and CRC. 3.3. To respect for the principles of impartiality, objectivity, non-selectivity, non-discrimination and avoidance of double standards and politicization.

3.4. To complement, rather than duplicate, the function of CEDAW and CRC Committees.

3.5. To recognize that the primary responsibility to promote and protect the fundamental freedoms and rights of women and children rests with each Member State. 3.6. To pursue a constructive erative approach to enhance the promotion and protection of rights of women and children. 
f. Upholding the Charter of the

United Nations and international

law, including international humanitarian law, subscribed by ASEAN

Member States; and

g. Respect for different cultures, languages and religions of the peoples of ASEAN, while emphasizing their common values in the spirit of unity women and children in ASEAN. in diversity.

2.2. Respect for international human rights principles, including universality, indivisibility, interdependence and interrelatedness of all human rights and fundamental freedoms, as well as impartiality, objectivity, non-selectivity, non-discrimination, and avoidance of double standards and politicization;

2.3. Recognition that the primary responsibility to promote and protect human rights and fundamental freedoms rests with each Member State;

2.4. Pursuance of a constructive and non-confrontational approach and cooperation to enhance promotion and protection of human rights; and 2.5. Adoption of an evolutionary approach that would contribute to the development of human rights norms and standards in ASEAN."

Mandates "4.1. To develop strategies for the and functions rights and fundamental freedoms to complement the building of the ASEAN Community;
3.7. To ensure a balance between the functions of promotion and protection of the rights of women and children.

\subsection{To adopt an evolutionary} approach that would contribute to the realization of the rights of 3.9. To adopt a collaborative and consultative approach with ASEAN Member States, academia and civil society pertaining to the rights of women and children."
"5.1. To promote the implementation of international instruments, ASEAN instruments and other instruments related to the rights of women and children. 
4.2. To develop an ASEAN Human

Rights Declaration with a view to establishing a framework for human rights cooperation through various ASEAN Conventions and other instruments dealing with human rights

4.3. To enhance public awareness of human rights among the peoples of ASEAN through education, research and dissemination of information;

4.4. To promote capacity building for the effective implementation of international human rights treaty obligations undertaken by ASEAN Member States;

4.5. To encourage ASEAN Member States to consider acceding to and ratifying international human rights instruments;
5. 2. To develop policies, programs and innovative strategies to promote and protect the rights of women and children to complement the building of the ASEAN Community.

5.3. To promote public awareness and education of the rights of women and children in ASEAN.

5.4. To advocate on behalf of women and children, especially the most vulnerable and marginalized, and encourage ASEAN Member States to improve their situation.

5.5. To build capacities of relevant stakeholders at all levels, e. g. administrative, legislative, judicial, civil society, community leaders, women and children machineries, through the provision of technical assistance, training and workshops, towards the realization of the rights of women and children.

4.6. To promote the full implemen- 5.6. To assist, upon request by tation of ASEAN instruments related ASEAN Member States, in preparto human rights; ing for CEDAW and CRC Periodic Reports, the Human Rights Council's Universal Periodic Review (UPR) and reports for other Treaty Bodies, with specific reference to the rights of women and children in ASEAN. 
4.7. To provide advisory services and technical assistance on human rights matters to ASEAN sectoral bodies upon request;

4.8. To engage in dialogue and consultation with other ASEAN bodies and entities associated with ASEAN, including civil society organizations and other stakeholders, as provided for in Chapter V of the ASEAN Charter;

4.9. To consult, as may be appropriate, with other national, regional and international institutions and entities concerned with the promotion and protection of human rights;

4.10. To obtain information from ASEAN Member States on the promotion and protection of human rights;

4.11. To develop common approaches and positions on human rights matters of interest to ASEAN;
5.7. To assist, upon request by ASEAN Member States, in implementing the Concluding Observations of CEDAW and CRC and other Treaty Bodies related to the rights of women and children.

5.8. To encourage ASEAN Member States on the collection and analysis of disaggregated data by sex, age, etc. related to the promotion and protection of the rights of women and children.

\subsection{To promote studies and} research related to the situation and well-being of women and children with the view to fostering effective implementation of the rights of women and children in the region.

5.10. To encourage ASEAN Member States to undertake periodic reviews of national legislations, regulations, policies, and practices related to the rights of women and children.

5.11. To facilitate sharing of experiences and good practices, including thematic issues, between and among ASEAN Member States related to the situation and well-being of women and children and to enhance the effective implementation of CEDAW and CRC through, among others, exchange of visits, seminars and conferences. 
4.12. To prepare studies on thematic 5.12 . To propose and promote issues of human rights in ASEAN; appropriate measures, mechanisms and strategies for the prevention and elimination of all forms of violation of the rights of women and children, including the protection of victims.

4.13. To submit an annual report on its activities, or other reports if deemed necessary, to the ASEAN Foreign Ministers Meeting; and

4.14. To perform any other tasks as may be assigned to it by the ASEAN Foreign Ministers Meeting."
5.13. To encourage ASEAN Member

States to consider acceding to, and ratifying, international human rights instruments related to women and children.

5.14. To support the participation of ASEAN women and children in dialogue and consultation processes in ASEAN related to the promotion and protection of their rights.

5.15. To provide advisory services on matters pertaining the promotion and protection of the rights of women and children to ASEAN sectoral bodies upon request. 5.16. To perform any other tasks related to the rights of women and children as may be delegated by the ASEAN Leaders and Foreign Ministers."

SOURCE: ASEAN Intergovernmental Commission on Human Rights, 'Terms of Reference' (ASEAN 2009) 3-7 <www.asean.org/storage/images/archive/publications/TOR-of-AICHR.pdf>; ASEAN Commission on the Promotion and Protection of the Rights of Women and Children, 'Terms of Reference' (ASEAN 2010) 2-8 <acwc.asean.org/wp-content/uploads/2016/o4/TORACWC.pdf $>$, both accessed 3 October 2020 . 